\title{
PERAN AWARENESS OF CONSEQUENCES TERHADAP PERILAKU PRO-LINGKUNGAN PADA WARGA JAKARTA
}

\author{
Fitri Arlinkasari, Riselligia Caninsti, dan Muh. Arief Prasetya \\ Fakultas Psikologi Universitas YARSI \\ Email: riselligia.caninsti@gmail.com
}

\begin{abstract}
ABSTRAK. Menurut laporan Kementrian Lingkungan Hidup dan Kehutanan Republik Indonesia, pada tahun 2018, Provinsi DKI Jakarta merupakan daerah yang memiliki indeks kualitas lingkungan hidup yang cukup rendah, dengan kisaran nilai 35.78\%. Fakta ini juga diungkapkan oleh dinas kebersihan DKI Jakarta pada tahun 2016 bahwa Jakarta merupakan kota besar yang menghasilkan sampah yang cukup banyak, yaitu $6.5-7$ ton per hari. Permasalahan sampah tidak terlepas dari perilaku manusia yang kurang memperhatikan kondisi lingkungannya. Perilaku membuang sampah sembarangan kini sudah menjadi kebiasan masyarakat dan dianggap sebagai hal yang biasa. Untuk mengurangi sampah yang jumlahnya semakin banyak diperlukan kesadaran masyarakat untuk berperilaku pro-lingkungan. Perilaku pro-lingkungan dipengaruhui oleh beberapa faktor salah satunya adalah awareness of consequences (AC). AC adalah kecenderungan untuk menjadi sadar atas konsekuensi atau dampak dari perilaku kita pada orang lain. Penelitian ini bertujuan untuk melihat apakah AC berperan terhadap perilaku pro-lingkungan pada masyarakat Jakarta. Peneliti menggunakan metode penelitian kuantitatif dengan tipe korelasional dengan Incidental Sampling. Penelitian ini memiliki sampel sebanyak 332 responden dengan beberapa karakteristik demografi. Berdasarkan hasil uji regresi ditemukan bahwa AC memiliki peran terhadap perilaku pro lingkungan. Hal ini menunjukkan bahwa semakin tinggi AC yang dimiliki seseorang, maka semakin tinggi juga perilaku pro-lingkungan seseorang. Peran AC terhadap perilaku pro-lingkungan dapat dilihat dari nilai $R$ Square Change sebesar 0,171 atau $17 \%$. Hal ini berarti awareness of consequences berperan sebesar $17 \%$ dan $83 \%$ dipengaruhui oleh faktor-faktor yang lain.
\end{abstract}

Kata kunci: awareness of consequences, AC, perilaku pro-lingkungan, masyarakat Jakarta

\section{THE ROLE OF AWARENESS OF CONSEQUENCES TO PRO-ENVIRONMENTAL BEHAVIOR IN JAKARTA RESIDENTS}

\begin{abstract}
DKI Jakarta is a province that has a fairly low environmental quality index, with a value range of 35.78\% (Ministry of Environment report, 2018). This fact is supported by the Jakarta cleanliness agency (2016) that Jakarta is a big city that produces a large amount of waste, which is 6.5-7 tons per day. The waste problems cannot be separated from human behavior that is less concerned about the condition of the environment. Littering behavior now has become a habit of society and considered normal. To reduce waste many people have to act pro-environment behaviors. Pro-environmental behavior is influenced by several factors, of which the awareness of the consequences $(A C)$ is one of the factors. Awareness of the consequences is the tendency to become aware of the consequences or effects of our behavior on others. This study aimed to see whether AC of pro-environmental behavior in the people of Jakarta. Researchers used quantitative research methods with correlational type with incidental sampling. This study had 332 respondents with various demographic characteristics. Based on regression test, it was found that AC has a significant role to PEB. This showed a high AC that a person has, the higher one's pro-environment behavior. The role of AC of pro-environmental behavior can be seen from the value of $R$ Square Change of 0.171 or $17 \%$. This means AC had a role by $17 \%$ and $83 \%$ influenced by other factors.
\end{abstract}

Keywords: awareness of consequences; AC; pro-environmental behavior; Jakarta people

\section{PENDAHULUAN}

Dunia sedang menghadapi masalah lingkungan yang serius yang berhubungan dengan pemanasan global, polusi udara perkotaan, dan kelangkaan air minum (DuNann Winter \& Koger, 2004; Gardner \& Stern, 2002; Vlek \& Steg, 2007 dalam Steg, dkk, 2014). Permasalahan lingkungan pada negara berkembang telah menjadi sorotan dunia (United Nations Environment Programme, 2013). Salah satu permasalahan pada negara berkembang adalah masyarakatnya masih kurang memiliki kepekaan terhadap kerusakan lingkungan di sekitarnya (Phuphisith, Kurisu, Hanaki, 2017). Hal ini disebabkan oleh budaya yang diterapkan masih berfokus kepada tujuan untuk mencapai kesejahteraan ekonomi, sedangkan pada negara maju kesejahteraan ekonomi telah tercapai sehingga fokus utamanya berhubungan kualitas hidup yang baik (Willuweit, 2009). Selain itu, menurut hasil studi yang dilakukan oleh Dunlap dan Mertig (1995) menemukan bahwa masyarakat pada negara maju lebih peduli terhadap perlindungan lingkungan hidup dibandingkan dengan masyarakat pada negara berkembang. Berbicara mengenai hal itu, 
Indonesia yang merupakan salah satu negara berkembang memiliki beragam permasalahan lingkungan, mulai dari pencemaran air yang disebabkan oleh merkuri dan limbah, polusi udara yang disebabkan oleh karbon monoksida, sampai pencemaran tanah yang disebabkan oleh pestisida (Surnaryo, n.d; Asian Development Bank, 2005; Environmental Performance Index, 2014 ).

Kondisi kerusakan lingkungan sejenis juga terlihat jelas di Jakarta. Kepala Badan Pengendalian Lingkungan Hidup DKI Jakarta, mengungkapkan bahwa kondisi lingkungan Jakarta dalam keadaan krisis. Hal tersebut disebabkan oleh pencemaran dan kerusakan lingkungan hidup yang umumnya berasal dari kegiatan industri, pemukim, perkantoran, jasa akomodasi dan kegiatan masyarakat (Purwoko, 2010). Pada tahun 2017, Provinsi DKI Jakarta merupakan daerah yang memiliki Indeks Kualitas Lingkungan Hidup (IKLH) yang cukup rendah dengan kisaran nilai $35.78 \%$, angka ini berada di bawah IKLH nasional yang memiliki nilai 56.46\% (Kementerian Lingkungan Hidup dan Kehutanan Republik Indonesia, 2018). Fakta mengenai rendahnya kualitas lingkungan hidup di Jakarta juga diungkapkan oleh Dinas Kebersihan DKI Jakarta (2016), bahwa Jakarta merupakan kota besar yang menghasilkan sampah yang cukup banyak dengan kisaran 6,5-7 ton per hari dan jumlah sampah yang tidak terangkut berjumlah 0.7 ton per hari (Databoks, 2016). Setiap tahun penduduk Jakarta selalu bertambah. Pada tahun 2015 penduduk Jakarta berjumlah 10,18 juta jiwa dan pada tahun 2017 bertambah menjadi 10,37 juta. Jumlah ini menandakan setiap tahun banyak masyarakat yang beralih ke perkotaan, selain dari jumlah penduduk yang menetap. Di Jakarta, orang yang masukke Jakarta pada sianghariuntuk bekerja sebanyak 1,38 juta jiwa. Semakin bertambahnya penduduk di Jakarta maka semakin banyak sampah yang dihasilkan (Databoks, 2018). Sampah yang tidak terkelola dengan baik juga merupakan salah satu penyebab utama masalah lingkungan lainnya. Sampah yang tidak terkelola tersebut dikarenakan banyaknya masyarakat yang membuang sampah tidak pada tempatnya. Menurut Hadiwiyoto (dalam Kahfi, 2017) sampah yang tidak terkelola dengan baik dapat menimbulkan berbagai macam gangguan seperti menghasilkan bau yang tidak sedap dan menurunkan kandungan oksigen di daerah sekitar sampah. Selain itu, gas-gas yang dihasilkan selama degradasi (pembusukan) sampah dapat membahayakan kesehatan karena gas dapat mengeluarkan racun, dan juga secara estetika dapat mengganggu pemandangan. Permasalahan sampah tidak terlepas dari perilaku manusia yang kurang memperhatikan kondisi lingkungannya. Perilaku membuang sampah sembarangan kini sudah menjadi kebiasan masyarakat dan menganggap perilaku tersebut sebagai hal yang biasa. Padahal masyarakat juga mengetahui secara pasti bahwa perilaku membuang
Selain perilaku membuang sampah sembarangan, banjir juga terjadi akibat banyaknya pemukiman liar di bantaran sungai yang mengganggu arus saluran air dan aktivitas masyarakat di wilayah aliran sungai. Pada tahun 2016, sebanyak 53 bangunan liar di bantaran Ciliwung kota Jakarta Timur ditertibkan. Di daerah Kampung Arus ada 39 bangunan liar yang ditertibkan karena akan ada normalisasi sungai agar aliran air menjadi lancar (Hadi, 2017; Aziz, 2017). Data BNPB pada tahun 2017 menunjukkan bahwa secara umum, masalah banjir di Jakarta merupakan akibat dari aktivitas masyarakat yang kurang memiliki kesadaran akan lingkungan seperti membuang sampah bukan pada tempatnya. Tradisi, perilaku, dan budaya masyarakat masih cenderung mencari jalan pintas dan mudah, kurang menghargai terhadap aturan dan hukum, serta tingkat disiplin yang belum kondusif. Semuanya berpotensi membahayakan masyarakat banyak dan merugikan nilai teknologi dalam implementasi energi nuklir untuk pembangkit tenaga listrik dan kebutuhan lainnya. Berbagai peristiwa yang tidak terduga seperti kerusuhan massal dan bencana alam selama lima tahun terakhir memberikan catatan yang memprihatinkan. Khususnya, bencana alam seperti banjir, gempa bumi, gunung berapi, dan lain sebagainya merupakan kendala alamiah yang patut dipertimbangkan secara cermat (Subijanto, 2004).

Berdasarkan beberapa masalah yang telah diuraikan di atas dapat disimpulkan bahwa salah satu penyebab utama menurunnya kualitas lingkungan di perkotaan, terutama Jakarta adalah perilaku manusia, seperti kurangnya inisiatif untuk menjaga lingkungan dan kebiasan buruk yang tidak memperhatikan kelangsungan lingkungan (KLH, 2012). Untuk mencegah dampak kerusakan lingkungan, diperlukan kepedulian masyarakat akan pentingnya perilaku pro-lingkungan.

Kollumuss dan Agyeman (2002) mendefinisikan perilaku pro-lingkungan sebagai kegiatan yang secara sadar mencoba untuk meminimalkan dampak negatif dari suatu tindakan terhadap lingkungan. Selain itu, Stern (2000) mengamati bahwa perilaku pro-lingkungan dipengaruhi oleh niat individu. Perilaku pro-lingkungan merupakan tindakan untuk mengubah lingkungan kembali normal. Pada masyarakat Jakarta, perilaku pro-lingkungan terlihat dari kegiatan komunitas peduli lingkungan dan warga masyarakat yang ikut serta dalam gerakan pungut sampah dalam rangka hari peduli sampah nasional tahun 2018 (Lingkungan Hidup Jakarta, 2018).

Pada studi ini, peneliti berfokus pada kesadaran konsekuesi (Awareness of Consequnces) sebagai faktor yang dapat mempengaruhi perilaku pro-lingkungan. Hal ini dikarenakan dalam teori norma-aktivasi yang dikembangkan oleh Schwartz (1968), perilaku pro-lingkungan harus muncul ketika seseorang menyadari konsekuensi dari 
perilaku mereka terhadap lingkungan. Artinya, kesadaran seseorang akan konsekuensi atas perilaku akan menentukan peluang munculnya perilaku pro-lingkungan. Selain itu peneliti memilih untuk melihat Awareness of Consequnces dikarenakan banyaknya fenomenya yang terjadi yang diakibatkan oleh perilaku manusia itu sendiri.

Awareness of Consequences (AC) adalah kecenderungan untuk menjadi sadar atas konsekuensi atau dampak dari perilaku kita pada orang lain (Schwartz, 1968). Parapsikologsosialtelahlamaberpendapatbahwabagaimana individu cenderung berperilaku dalam situasi tertentu dapat diprediksi dengan melihat kesadarannya akan konsekuensi atas perilaku tersebut. Awareness of consequences didefinisikan sebagai kesadaran akan adanya konsekuensi negatif bagi orang lain atau hal-hal lain bila individu tidak bertindak prososial (De Groot, 2009). Dalam teori Value-Belief-Norms (VBN), awareness of consequences mengacu pada keyakinan tentang konsekuensi atas perilaku tertentu yang dapat merugikan lingkungan atau menambah masalah lingkungan (Stern, 2000; Stern, et al., 1999).

Joireman, Lasane, Bennet, Richards, dan Solaimani (2001) mengatakan bahwa awareness of consequences dapat mempengaruhi perilaku pro-lingkungan. Dari hasil penelitian yang dilakukan oleh Mohana (2010), bahwa semakin tinggi awareness of consequences maka semakin tinggi pula perilaku pro-lingkungan seseorang. Bronfman dkk (2015) menambahkan, bahwa masyarakat perlu didorong untuk memiliki tingkat kesadaran yang tinggi akan konsekuensi perilakunya terhadap lingkungan agar lingkungan hidup yang lebih baik dapat tercipta melalui pembentukan perilaku yang lebih ramah lingkungan.

Berdasarkan pemaparan di atas, peneliti tertarik untuk mengkaji apakah terdapat peran awareness of consequences terhadap perilaku pro-lingkungan pada masyarakat Jakarta. Peneliti melihat masih banyak masyarakat yang kurang memperhatikan lingkungan karena kurangnya kesadaran akan lingkungan. Selain itu, di Indonesia khususnya kota-kota besar, penelitian yang secara khusus meneliti faktor-faktor psikologis yang mempengaruhi pembentukan perilaku pro-lingkungan masih sangat terbatas. Penelitian ini diharapkan dapat memberikan informasi yang komprehensif pada masyarakat dan pemerintah kota tentang upaya yang dapat dilakukan untuk meningkatkan kualitas lingkungan hidup melalui perubahan perilaku masyarakat. Penelitian ini dilakukan di Jakarta dikarenakan banyaknya fenomena yang diakibatkan oleh manusia seperti yang dapat kita lihat dari fenomena yang ada di atas yang sudah dijelaskan sebelumnya seperti membuang sampah sembarangan, penggunaan energi yang berlebihan dan peningkatan kendaraan bermotor yang pesat.

\section{METODE}

Penelitian ini menggunakan pendekatan kuantitatif dengan tipe korelasional (Sugiyono, 2013). Subjek dalam penelitian ini berjumlah 332 orang dengan kriteria, laki-laki atau perempuan dewasa (21-65 tahun; Papalia \& Feldman, 2014)yang bertempat tinggal di Jakarta. Teknik pengambilan sampel yang digunakan adalah incidental sampling.

Dalam penelitian ini, perilaku pro-lingkungan diukur menggunakan alatukur General Environmental Behavior yang dikembangkan oleh Kaisser pada tahun 1998 dan dimodifikasi oleh Bronfman, Cisternas, Lopez-Vazquez, Ia Maza, dan Oyanedel (2015). Kemudian alat ukur tersebut diadaptasi ke dalambahasaIndonesia.AlatukurinimenggunakanskalaLikert dan memiliki reliabilitas sebesar 0.861. Blueprint alat ukur General Environmental Behavior dapat dilihat di tabel 1.

Dalam mengukur awareness of consequences, peneliti menggunakan alat ukur Awareness of Consequences Scale yang dikembangkan oleh Stern (2000) yang kemudian diadaptasi ke dalam bahasa Indonesia. Alat ukur ini juga menggunakan skala Likert dan memiliki reliabilitas sebesar 0.630 .

Tabel 2. Blueprint alat ukur Awareness of Consequences

\begin{tabular}{|l|l|l|l|}
\hline $\begin{array}{l}\text { Faktor yang } \\
\text { diukur }\end{array}$ & Dimensi & Pernyataan & Item \\
\cline { 3 - 4 } & & & $\mathrm{F}$ \\
\hline $\begin{array}{l}\text { Awareness of } \\
\text { Consequences }\end{array}$ & & $\begin{array}{l}\text { Melindung i } \\
\text { ling ku gan } \\
\text { hidup akan } \\
\text { meningkatkan } \\
\text { kualitas hidup } \\
\text { bagi semua } \\
\text { orang }\end{array}$ & $1,2,3,4,5,6$ \\
\hline
\end{tabular}

Proses adaptasikeduaalatukurdalampenelitian inidari Bahasa Inggris ke bahas Indonesia dilakukan oleh peneliti dengan menerjemahkan aitem-aitem dari bahasa Inggris ke bahasa Indonesia dengan bantuan penerjemah. Setelah mendapatkan hasil terjemahan dalam bahasa Indonesia, peneliti melakukan diskusi sehingga mendapatkan aitemaitem dalam bahasa Indonesia yang lebih sesuai. Kemudian peneliti melakukan back translation melalui bantuan penerjemah untuk melihat kesesuaian makna dengan aitem awal. Setelah melewati proses terjemah, diskusi dengan pembimbing, dan back translation, peneliti melakukan proses expert judgement yang diajukan kepada Pusat Psikometri Terapan (P2T) Universitas YARSI agar alat ukur tersebut dianalisa oleh ahli yang kompeten di bidangnya. Sementara itu, uji statistik dalam penelitian ini menggunakan analisis regresi. Hal ini dilakukan untuk melihat besaran peranan variabel bebas terhadap varibel terikat. 
Tabel 1. Blueprint alat ukur General Environmental Behavior

\begin{tabular}{|l|l|l|l|l|}
\hline $\begin{array}{l}\text { Faktor yang } \\
\text { diukur }\end{array}$ & & Contoh Item & \multicolumn{2}{l|}{ Item } \\
\hline & & & Favorable & $\begin{array}{l}\text { Unfavor- } \\
\text { able }\end{array}$ \\
\hline $\begin{array}{l}\text { Perilaku } \\
\text { Pro-Lingkungan }\end{array}$ & Power Conservation & Saya mematikan lampu ketika tidak menggunakannya & $\begin{array}{l}1,2,3,4,5, \\
6,7\end{array}$ & \\
\hline & $\begin{array}{l}\text { Ecologically Aware Consumer } \\
\text { Behavior }\end{array}$ & $\begin{array}{l}\text { Saya membeli deterjen biodegradable (mudah diurai } \\
\text { oleh media lingkungan, seperti tanah dan air) untuk } \\
\text { mencuci pakaian }\end{array}$ & $8,9,10,11$ & \\
\hline & Biodiversity Protection & Saya mengunjungi taman nasional dan/atau cagar alam & $12,13,14$ & $1,1,19,19$ \\
\hline & Water Conservation & $\begin{array}{l}\text { Saya mencoba untuk mandi menggunakan shower/pan- } \\
\text { curan kurang dari lima (5) menit }\end{array}$ & 15,17 \\
\hline & Rational Automobile Use & $\begin{array}{l}\text { Saya tidak berkendara di hari ketika polusi udara men- } \\
\text { capai level yang tinggi }\end{array}$ & $\begin{array}{l}20,21,22, \\
23,24\end{array}$ & 25 \\
\hline & Ecological Waste Management & $\begin{array}{l}\text { Saya menggunakan kembali kantong plastik yang saya } \\
\text { dapat dari supermarket }\end{array}$ & $\begin{array}{l}26,27,28,29, \\
30,31,32\end{array}$ & \\
\hline
\end{tabular}

\section{HASIL DAN PEMBAHASAN}

Berikut merupakan deskripsi demografi subjek dalam penelitian ini:

Tabel 3. Deskripsi Subjek Penelitian

\begin{tabular}{|l|r|r|}
\hline Demografi & Jumlah & Presentase \\
\hline Jenis Kelamin & 124 & $37,3 \%$ \\
\hline Laki-laki & 208 & $62,7 \%$ \\
\hline Perempuan & & \\
\hline Usia & 228 & $86,7 \%$ \\
\hline $21-39$ & 44 & $13,3 \%$ \\
\hline $40-65$ & & $68,07 \%$ \\
\hline Penghasilan & 226 & $31,93 \%$ \\
\hline $0-$ Rp 3.500.000* & 106 & \\
\hline $\begin{array}{c}\text { Rp.3.500.001- } \\
\text { Rp. 25.000.000 }\end{array}$ & & \\
\hline
\end{tabular}

* Berdasarkan rata-rata upah minimum DKI Jakarta tahun 2017

Peneliti melakukan preliminary analysis sebelum menguji analisis hasil penelitian. Tujuannya adalah untuk mengontrol faktor-faktor lain yang dapat mempengaruhi variabel terikat. Preliminary analysis dilakukan dengan uji korelasi antara faktor-faktor yang mempengaruhi perilaku pro-lingkungan untuk melihat apakah data tersebut menunjukkan hubungan antara perilaku pro-lingkungan dengan faktor demografi yang mempengaruhinya. Terdapat tiga faktor demografi yang dapat mempengaruhi perilaku prolingkungan, yaitu jenis kelamin, usia, dan SES (penghasilan).

\section{Tabel 4. Hasil Uji Premiliniary}

\begin{tabular}{|l|l|}
\hline $\begin{array}{l}\text { Faktor-faktor yang mempen- } \\
\text { garuhi Perilaku Pro-Lingkungan }\end{array}$ & \multicolumn{1}{|c|}{ Sig. } \\
\hline Usia & 0,470 \\
\hline Jenis Kelamin & 0,147 \\
\hline Penghasilan & 0,002 \\
\hline
\end{tabular}

Dari tabel di atas, menunjukkan bahwa penghasilan dapat mempengaruhi perilaku pro-lingkungan secara tidak langsung, sedangkan usia dan jenis kelamin menunjukkan pesebaran data yang tidak merata sehingga tidak dapat menunjukkan pengaruh terhadap variabel terikat.

Sebelum melakukan analisis regresi, peneliti melakukan perhitungan uji normalitas, linearitas, dan korelasi sebagai syarat untuk melihat apakah dapat dilakukan analisis regresi. Hasil dari ketiga perhitungan tersebut menunjukkan bahwa data dalam penelitian ini terdistribusi normal, kedua variabel memiliki hubungan yang linier, dan memiliki hubungan positif yang signifikan. Oleh karena itu, data dalam penelitian ini memenuhi syarat untuk dilakukan analisis regresi. Berikut hasil dari analisis regresi pada penelitian ini:

Tabel 5. Hasil Uji Regresi

\begin{tabular}{|l|l|l|l|l|}
\hline \multicolumn{1}{|c|}{ Model } & \multicolumn{1}{|c|}{$\mathrm{R}$} & \multicolumn{1}{|c|}{ R Square } & $\begin{array}{l}\text { R Square } \\
\text { Change }\end{array}$ & \multicolumn{1}{|c|}{ Sig. } \\
\hline 1 & 0,124 & 0,15 & 0,15 & 0,217 \\
\hline 2 & 0,431 & 0,186 & 0,171 & 0,001 \\
\hline
\end{tabular}

Model 1 : Peran penghasilan-perilaku pro lingkungan

Model 2 : Peran awareness of consequences-perilaku pro lingkungan

Pada penelitian ini ditemukan pula korelasi positif antara awareness of consequences dengan perilaku prolingkungan, hal ini menunjukan bahwa semakin tinggi awareness of consequences yang dimiliki seseorang, maka semakin tinggi juga perilaku pro-lingkungan seseorang. Hal ini sejalan dengan penelitian Mohana (2010), bahwa semakin tinggi awareness of consequences maka semakin tinggi pula perilaku pro-lingkungan seseorang. Penelitian ini juga didukung oleh penelitian yang dilakukan oleh Eagly dan Chaiken (Christensen, Needham, \& Rowe, 2009) yang menunjukkan bahwa awareness of consequences dapat mempengaruhi perilaku seseorang. Teori VBN yang dibuat oleh Stern (2000) menyatakan bahwa nilai-nilai yang dimiliki seseorang berpengaruh terhadap cara pandang 
cara pandang seseorang terhadap lingkungannya dan berpengaruh terhadap awareness of consequences individu, atau keyakinan individu bahwa perilakunya dapat berdampak pada kondisi lingkungan. Menurut Ajzen (1991), perilaku didasarkan pada faktor kehendak yang melibatkan pertimbangan-pertimbangan untuk me-lakukan atau tidak melakukan suatu perilaku. Dalam prosesnya, berbagai pertimbangan tersebut akan membentuk intensi untuk melakukan suatu perilaku.

Berdasarkan hasil uji regresi yang dilakukan dalam penelitian ini ditemukan bahwa nilai $\mathrm{r}=0,431 \quad(\mathrm{p}=0,001)$. Hal ini menunjukkan bahwa awareness of consequences berperan terhadap perilaku pro-lingkungan masyarakat Jakarta. Oleh karena itu, hipotesis alternatif dalam penelitian ini dapat diterima yaitu terdapat peran awareness of consequences terhadap perilaku pro-lingkungan masyarakat Jakarta. Hal ini sejalan dengan penelitian Schwartz (1968), yang mengatakan bahwa faktor awareness of consequences secara langsung mempengaruhi perilaku pro-lingkungan. Perilaku pro-lingkungan harus muncul ketika seseorang menyadari konsekuensi dari perilaku mereka terhadap lingkungan. Artinya, kesadaran seseorang akan konsekuensi atas perilaku akan menentukan peluang munculnya perilaku pro-lingkungan. Di dalam penelitian ini, ditemukan bahwa peran awareness of consequences adalah sebesar 17\% terhadap perilaku pro-lingkungan, dimana $1 \%$ dipengaruhi oleh peng-hasilan dan $82 \%$ nya merupakan pengaruh dari faktor-faktor lainnya. Menurut Bronfman, dkk. (2015), ada beberapa faktor yang dapat mempengaruhi perilaku pro-lingkungan di antaranya new ecological paradigm, norma personal, nilai personal, ascription of responsibility, willingness to sacrifice, dan lain-lain. Banyak orang yang memiliki kesadaran lingkungan yang tinggi, tetapi menganggap perlindungan terhadap lingkungan merupakan tanggung jawab pemerintah atau perusahaan-perusahaan besar (Laroche, Bregeron, \& Forleo, 2001). Bell et al (dalam Nordlund \& Garvill, 2002) mempelajari kesadaran lingkungan dan peri-laku pro-lingkungan, kemudian menyimpulkan bahwa perilaku melestarikan lingkungan tidak pasti muncul meskipun seseorang memiliki kesadaran lingkungan yang tinggi. Menurut Oluyinka dan Balogun (2010), sikap lingkungan memperkuat hubungan antara sifat bawaan individu dan perilaku lingkungannya. Selain itu, apabila seseorang memiliki konsep diri yang tinggi maka dapat me-ningkatkan perilaku pro-lingkungan dan lebih cenderung terlibatdalam lingkungan. Tanpapeningkatan citra diri individu perilaku pro-lingkungan tidak akan membaik.

Pada uji demografi, individu yang memiliki penghasilan kurang dari Rp. 3.500.000 memiliki nilai rata-rata yang lebih rendah terhadap perilaku pro-lingkungan dibandingkan dengan individu yang memiliki penghasilan lebih dari Rp. 3.500.000/bulan. Hal ini sejalan dengan penelitian Inglehart pada tahun 1995 yang menunjukkan bahwa warga negara yang lebih kaya rata-rata memiliki perhatian terhadap lingkungan yang lebih besar. Perbedaan dalam perhatian lingkungan berdasarkan status sosial juga dapat terjadi karena adanya globalisasi terhadap lingkungan hidup (Giffordetal, 2014). Para penduduk negara-negara miskin (misalnya Hungaria, Nigeria) tampaknya lebih memperhatikan masalah lingkungan daripada warga negara kaya (misalnya Belanda, AS) (Brechin, dalam Gifford \& Nilsson, 2014). Hal ini mungkin terjadi karena sebagian besar masyarakat memiliki masalah lingkungan di masyarakat (Gifford \& Nilsson, 2014).

Penelitian ini memiliki kelemahan, yaitu jumlah subjek 322 orang belum menunjukkan sampel yang representatifdari warga Jakarta. Di samping kelemahan penelitian, terdapat pula kelebihan dari penelitian ini antara lain penelitian ini masih sangat jarangan diteliti bahkan di Indonesia belum ada penelitian yang membahas tentang variabel perilaku pro-lingkungan dan awareness of consequences. Hasil dari penelitian ini bisa menjadi pedoman bagi penelitian selanjutnya yang juga membahas tentang variabel perilaku pro-lingkungan dan awareness of consequences.

\section{SIMPULAN}

Hasil dari penelitian yang dilakukan kepada 332 responden menunjukan bahwa awareness of consequences berperan secara signifikan terhadap perilaku pro-lingkungan pada masyarakat Jakarta. Pada penelitian selanjutnya diharapkan peneliti dapat menambah jumlah sampel yang lebih merepresentasikan warga Jakarta dari aspek demografi seperti: jenis kelamin, usia, penghasilan dan lain sebagainya, sehingga diperoleh hasil yang lebih komprehensif. Pada penelitian selanjutnya, disarankan pula untuk melihat peran faktor-faktor lain dalam teori Norm Activation Model yang dapat mempengaruhui perilaku pro-lingkungan. Penelitian selanjutnya juga dapat melihat gambaran awareness of consequencess pada warga Jakarta dan masyarakat Indonesia secara umum, hal ini dilatarbelakangi oleh penjelasan pada awal penelitian yang menunjukkan bahwa banyaknya permasalahan dan fenomena yang terjadi di lingkungan sosial yang diakibatkan oleh perilaku manusia.

\section{DAFTAR PUSTAKA}

Adminfd. (2016). Fenomena Banjir di DKI Jakarta Tahun 2014-2016. Di unduh pada tanggal 8 november 2016, daripada http://faktadki.com/2016/11/08/fenomenabanjir-di-dki-jakarta-tahun-2014-2016/

Ajzen, I. (1991). The theory of planned behavior. Organizational Behavior and Human Decision Processes, 50(2), 179-211. 
Aziz, K. R. (2017). Pemprov DKI Akan Tertibkan 39 Bangunan Liar di Kampung Arus. Diunduh pada tangal 16 Februari 2017 daripada http://megapolitan.kompas.com/read/2017/02/16/19381871/pemprov.dki. akan.tertibkan.39.bangunan.liar.di.kampung.arus.

BNPB. Data dan Informasi Bencana. Diakses dari tanggal 11 Maret 2017 dari http://dibi.bnpb.go.id/

BPPT (2014). Outlook Energi Indonesia 2014: Pengembangan Energi untuk Mendukung Program Subtitusi BBM, Jakarta, Pusat Teknologi Pengembangan Sumberdaya Energi

Badan Pusat Statistik Provinsi DKI Jakarta. (2016). Jakarta Dalam Angka. Jakarta: BPS Provinsi DKI Jakarta.

Bronfman, N. C., Cisternas, P. C., Vázquez, E. 1., Maza, C. D., and Oyanedel, J. C. (2015). Understanding attitudes and pro - environmental behaviors in a Chilean community. Sustainability, 7, 14133-14152; doi:10.3390/su71014133

Christensen, A., Needham, M. D., Rowe, S. (2009). Whale Watchers' Past Experience, Value Orientations, And Awareness Of Consequences Of Actions On The Marine Environment. Tourism in Marine Environments, 5(4), 271-285.

Databoks. (2016). Produksi Sampah per Hari di Enam Wilayah DKI Jakarta pada 2016. Diunduh pada tanggal 22 maret 2017 daripada http://databoks. katadata.co.id/datapublish/2017/03/22/produksisampah-per-hari-di-enam-wilayah-dki-jakarta-pada-2014.

De Groot, J. I. M., \&Steg, L.(2009). Morality and Prosocial Behavior: The Role of Awareness, Responsibility, and Norms in the Norm Activation Model. The Journal of Social Psychology, 149(4), 425-449.

Dunlap. R. E. Mertig. A.G. (1995). Global Concern For The Environmen: Is Affluence A Prerequisite: $J$. Soc. Issues, 51, 121-137.

Environmental Performance Index.(2014). Country Rankings, diakses dari http://archive.epi.yale.edu/epi/ country-rankings , 22 Febuari 2018.

Gifford, R., \&Nilsson, A. (2014). Personal and social factors that influence pro-environmental concern and behaviour: A review. International Journal of Psychology, 4 9(3), 141-157.

Hadi, F., 2017. BREAKING NEWS: 53 Bangunan Liar di Bantaran Ciliwung Dihancurkan. Diunduh pada tanggal 13 April 2017 daripada http://wartakota. tribunnews.com/2016/11/15/breaking-news-53-bangunan-liar-di-bantaran-ciliwung-dihancurkan.

Kementerian Lingkungan Hidup dan Kehutanan Republik Indonesia. (2018). Indeks Kualitas Lingkungan Hidup Indonesia 2017. Diunduh www.menlhk.go.id/ downlot.php?file=IKLH_2017.pdf
Kollmuss, A., \& Agyemann, J. (2002). The Mind Gap : Why Do People Act Environmentally and What are The Barriers to Pro-environmental Behavior. Environmental Education Research, 8(3) : 239-260.

Laroche, M., Bregeron, J., \& Forleo, G. (2001). Targeting consumers who are willing to pay more for environmentally friendly product. Journal of Cosumers Marketing, 18(6), 503-520.

Lingkungan Hidup Jakarta.(2016). Lingkungan Hidup. Diunduh daripada http://data.jakarta.go.id/group/ lingkungan-hidup.

Lingkungan Hidup Jakarta. (2018). Diunduh dariapda https://lingkunganhidup.jakarta.go.id/ekspatriat-komunitas-peduli-lingkungan-dan-warga-masyarakat-ikut-serta-gerakan-pungut-sampah-dalam-rangka-hari-peduli-sampah-nasional-tahun-2018/

Nordlund. A. M., \& Garvill, J. (2002). Value structure behind proenvironmental behavior.Environment and Behavior, 34(6), 740-756. DOI: 10.1177/001391602237244

Oluyinka. O. A.,\& Balogun. S. K. (2010). Environmental attitude as a mediator of the relationship between self-concept, environmental self-efficacy and responsible environmental behaviour among residents of high density areas in Ibadan Metropolis, Nigeria. Ethiopian Journal of Environmental Studies and Management, 3(2), 111 - 119.

Papalia, D. E., \& Feldman, R. D. (2014). Menyelami Perkembangan Manusia : Experience Human Development. Jakarta : Salemba Humanika,

Phuphisith, S., Kurisu, K., Hanaki, K. (2017). Insight into pro-environmental behaviors and people's perception in Bangkok, Thailand. Journal of Environmental Information Science, 45 (5). 9-20.

Purwoko, K. 2010. Kondisi Lingkungan Jakarta Krisis. Diunduh pada tanggal 04 november 2010 daripada http://www.republika.co.id/berita/breaking-news/ metropolitan/10/11/04/144328-kondisi-lingkungan-jakarta-krisis.

Ramadhiani, A, 2017. Ini Penyebab Banjir Jakarta Menurut UPC. Diunduh pada tanggal 16 oktober 2017 daripada http://properti.kompas.com/ $\mathrm{read} / 2017 / 02 / 21 / 193000321 /$ ini.penyebab.banjir.jakarta.menurut.upc.

Schwartz, S. H. 1968. Awareness of consequences and the influence of moral norms on interpersonal behavior. Sociometry, 31(4), 355-369.

Steg, L.; Bolderdijk, J.W.; Keizer K.; Perlaviciute, G. (2014). An Integrated Framework for Encouraging Pro-environmental Behaviour: The role of values, situational factors and goals. Journal of Environmental Psychology 38; $104-115$. 
Stern, P.C.; Dietz, T.; Abel, T.D.; Guagnano, G.A.; Kalof, L. A.(1999). Value-belief-norm theory of support for social movements: The case of environmentalism. Hum. Ecol, 6, 81-98.

Stern, P. C. (2000). Toward a coherent theory of environmentally significant behavior. Journal of Social Issues, 56(3), 407-424.

Subijanto, B. (2004). Pemanfaatan Energi Nuklir Untuk Pembangkit Listrik Tinjauan Dari Perspektif Intelijen. ISSN: 1412-2812

Sugiyono. (2013). Statistika untuk Penelitian. Bandung : ALFABETA.

Sunaryo, T. (n. d). Environmental Problems in Indonesia: A Review, diakses dari https://aic.gov. au/sites/default/files/publications/proceedings/ downloads/12-sunaryo.pdf, 22 Febuari 2018.

Suryono, D. D.,\& Moersidik, S. S. (2015). Kajian karakteristik Muara Ciliwung dengan model budget Nitrogen. Jurnal Manusia \& Lingkungan, 22(1), 32-38.

Turaga, R. M. R., Howarth, R. B., \& Borsuk, M. E. (2010). Pro-environmental behavior: rational choice meets moral motivation. Annals of the New York Academy of Sciences. 1185, 211-224

United Nations Environment Programme. (2013). UNEP 2013 Annual Report Spotlights Action on Key Environmental Issues, diakses dari https://www. unenvironment.org/news-and-stories/press-release/unep-2013-annual-report-spotlights-action-key-environmental-issues, 23 Febuari 2018.

Willuweit, L. (2009). Promoting Environmental Behavior: An Investigating of The Cross-Cultural Environmental Behavior Patterns. The Case Of Abu Dhabi, Tesis, Stockholm University, Stockholm. 